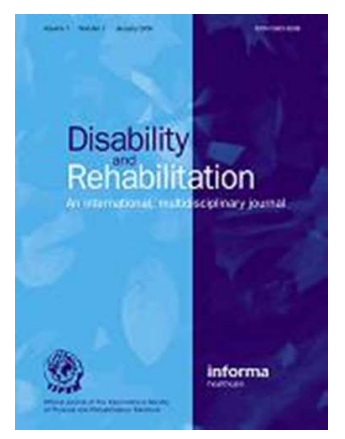

\title{
Cognitive functioning in persons with lower limb amputations: A review
}

\begin{tabular}{|r|l|}
\hline Journal: & Disability and Rehabilitation \\
\hline Manuscript ID: & TIDS-07-2011-077.R1 \\
\hline Manuscript Type: & Review \\
\hline Keywords: & cognition, amputation, lower limb, dementia, prosthetic \\
\hline
\end{tabular}

SCHOLARONE ${ }^{\text {IM }}$

Manuscripts 


\begin{abstract}
Purpose. To review the literature on cognitive functioning in persons with lower limb amputations.

Method. A search of the MEDLINE, PsycINFO and Web of Science databases was carried out.

$\underline{\text { Results. }}$ Thirty papers were found that met the inclusion criteria. The studies were characterised by heterogeneity of design, methodological quality, sample characteristics, assessment of cognitive functioning, and outcomes examined. The research published to date suggests that cognitive impairment is more prevalent among persons with lower limb amputations than in the general population, and is linked with a number of important outcomes in this patient group, including mobility, prosthesis use, and maintenance of independence following amputation.

Conclusions. These findings highlight the importance of assessing the cognitive abilities of persons with lower limb amputations. An understanding of the cognitive profile of these patients could assist rehabilitation teams in determining their suitability for prosthetic or wheelchair rehabilitation, ascertaining appropriate and realistic goals for rehabilitation, and tailoring rehabilitation programmes to patients' strengths so that maximal mobility and independence is achieved.
\end{abstract}


Introduction

The loss of a limb has significant physical, psychological, and social impacts on a person's life [1]. The principal aim of rehabilitation following lower limb amputation is to minimise these consequences by restoring mobility and ensuring that an acceptable level of functioning and participation is reached [2]. A prosthetic limb may be fitted in order to compensate for any functional losses obstructing the achievement of this goal. The activities engaged in during prosthetic rehabilitation, such as donning/doffing of the prosthesis and gait training, require not only the physical competencies of strength, balance and co-ordination, but also the cognitive capacity to learn these new skills and adapt them to different situations and environments [3-6]. Several areas of cognition are thought to be involved in successful prosthetic use and maintenance, including memory, attention and concentration, visuospatial function, and organisational skills $[7,8]$. Individuals with impairments in these domains are likely to face significant challenges in learning how to mobilise with a prosthetic limb, as they may struggle to retain new information and/or initiate new behaviours [9]. Cognitive impairment may also have a negative effect on the lives of individuals who are not fitted with a prosthesis following lower limb amputation [10], through its associations with other functional outcomes such as long-term institutionalisation and loss of independence in activities of daily living [11-13].

Individuals with lower limb amputations may be particularly susceptible to impairments in cognitive function for a number of reasons. Firstly, there has been a significant increase in the average age at which amputation occurs in recent years, due to improvements in the medical management of associated conditions such as diabetes and peripheral vascular disease [14]. Over half of all individuals referred to prosthetic centres in the U.K. every year are older than 65 years of age, and more than a quarter are aged over 75 years [15]. The rising age at which lower limb amputation is performed brings with it a 
heightened risk of cognitive impairment. Ageing is associated with declines in many aspects of cognitive function, including attention, memory, reasoning, and problem solving [16], even though intellectual performance may remain intact [17]. Older age is also associated with increased risk for dementia, a clinical syndrome characterised by a chronic or progressive deterioration in brain function that results in cognitive impairment. Between five and ten percent of all persons aged 65 years and older are affected by this condition, with the proportion reaching thirty percent among those aged over 80 years [12].

Secondly, some of the most prevalent causes of lower limb amputation, namely peripheral vascular disease and diabetes mellitus, are linked with deterioration in cognitive functioning. Peripheral vascular disease, which currently accounts for $82 \%$ of all amputations carried out in the U.S. each year [18], shares a common pathophysiological mechanism with cerebrovascular disease in atherosclerosis, as well as a number of common risk factors such as smoking and hypertension $[5,9,12,19]$. These shared characteristics may leave individuals with dysvascular amputations susceptible to vascular cognitive impairment [20,21], which affects approximately five percent of all persons aged over 65 years [22] and is characterised by deficits in attentional and executive functioning (the ability to organise cognitive processes e.g. planning and sequencing of actions) in addition to slowing of motor performance and information processing, with episodic memory remaining relatively intact $[8,20,23]$.Diabetes mellitus, which is present in almost half of all cases of lower limb amputation [24], is associated with increased incidence of dementia and accelerated decline in cognitive functioning [25-27].

Given its associations with dysvascularity and older age, it appears that cognitive impairment may be an issue of some importance for persons who have lost a lower limb, with significant implications for their post-amputation functioning. Indeed, two recent literature reviews provide evidence in support of this proposal. For example, of the thirteen studies 
included iin O'Neill's review of the literature on the cognitive, affective and demographic predictors of rehabilitation outcome in persons admitted to acute or postacute facilities for prosthetic limb fitting following lower limb amputation, eight observed that cognitive ability predicted functional outcome [9]. In addition, Sansam and colleagues [28] noted in their review paper that cognitive ability was consistently observed to be a significant predictor of post-rehabilitation walking ability following lower limb amputation.

The present study aims to build on the findings of these earlier articles by providing an up-to-date review of the published literature on cognitive functioning in persons with lower limb amputations. Many individuals who undergo amputation do not attend formal rehabilitation and are never fitted with a prosthesis [10], hence the scope of this review will be broadened to include all persons with lower limb amputations rather than rehabilitation inpatients being fitted with a prosthetic limb specifically. Furthermore, instead of focusing on mobility outcomes alone, all outcome variables associated with cognitive functioning in this population will be examined.. The purpose of this article is to synthesise current evidence regarding cognitive functioning in persons with lower limb amputations in terms of the prevalence of dementia and cognitive impairment, and to review the methods employed to assess cognitive ability, the areas of cognition most affected, and the outcomes associated with cognitive functioning.

Method

Search strategy

A computer-aided literature search of the MEDLINE (from 1948 to May 2011), PsycINFO (from 1911 to May 2011), and Web of Science (from 1945 to May 2011) databases was carried out to identify studies in which the cognitive functioning of persons with lower limb amputations was examined. The following keywords were used in the 
literature search: amput* and [cognit*, neuropsych* or dementia]. A supplementary search using the Google Scholar search engine was also conducted to identify studies that may not have been included in the databases above [29]. Abstracts for all citations obtained in the literature search were read by three of the authors (LC, DD and PG). In cases where an abstract was unavailable or ambiguous in terms of its relevance to the present review, the complete article was retrieved. The reference lists of previous literature reviews $[9,28]$ and studies selected for inclusion in the present review were also examined for relevant citations.

\section{Selection criteria}

Articles were selected for inclusion in the review if: (a) a group or subgroup of participants had unilateral or bilateral lower limb amputation and were aged 18 years and over; (b) cognitive functioning (or aspects thereof, e.g. memory) was assessed as a discrete variable (i.e. not as part of a composite score) and reported on in the results; (c) the article was written in English; and (d) the article was published in a peer-reviewed journal. Articles were excluded from the review if: (a) participants with lower limb amputations were not examined as a distinct group (e.g. were included in the same group as persons with upper limb amputations); (b) cognition was assessed only as a means of screening potential participants; (c) cognitive measures were employed incidentally in the research (e.g. used as a distractor task in assessments of balance and gait) and were not the focus of statistical analyses; and/or (d) the article was not published in a peer-reviewed journal.

\section{Quality assessment}

The overall quality of studies was assessed using an evidence appraisal methodology developed by the Scottish Intercollegiate Guidelines Network (SIGN) [30]. Using this methodology, the quality of evidence provided by each study was assessed by assigning an 
evidence level ranging from $1++$ to 4 , with eight possible ranks (see table 1 subscript for a description of each rank). For each study, the evidence level was determined by its design and a qualitative assessment of answers to critical appraisal checklists (only used in the case of randomised controlled trials or case-control/cohort studies). Each study included in the present review was appraised independently by two of the authors (LC and RL-V). In instances where the reviewers did not agree on the level of evidence to be assigned to a particular study, a consensus method was used to discuss and resolve the issue. If the disagreement persisted, papers were referred to a third author $(\mathrm{PG})$ to determine the evidence level.

\section{Results}

\section{Study selection}

On conducting the literature search, 183, 224, and 161 articles were found in the MEDLINE, PsycINFO and Web of Science databases, respectively. After removing citations that were indexed in more than one database, a total of 419 articles remained. Of these, 28 studies met the inclusion criteria. A further two studies meeting the inclusion criteria that did not appear in the database search were identified using Google Scholar, giving a total of thirty papers. These studies are summarised in table 1 , and are characterised by significant heterogeneity in terms of design, methodological quality, population, sample characteristics, method of cognitive assessment and outcome measures utilised.

$* * * * * * * * * * * * * * * * * * * * *$

Insert table 1 about here

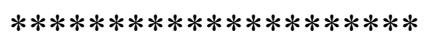




\section{Study design and methodological quality}

The evidence level of each study, as assessed using the SIGN methodology described earlier [30], is also displayed in table 1. Of the thirty articles selected for inclusion, two were randomised controlled trials [3,31], four were case-control studies [5,50-52], eighteen were cohort studies (fourteen retrospective [10,32-37,39-45], four prospective $[8,38,47,48]$ ), and six were cross-sectional studies (four analytic [4,7,46,49], two non-analytic [53,54]). As indicated by the evidence levels presented, the methodological quality of these studies varied widely in terms of robustness of study design, clarity and appropriateness of the research question and inclusion/exclusion criteria, statistical power, suitability of analyses employed (if any), and so forth. A study by Donaghey and colleagues [31] received the highest SIGN rating of $1++$, as its robust randomised control design and methodology suggested a very low risk of bias. A number of high quality, well-designed retrospective cohort studies were included in the review $[10,33,43,52,54]$. The highest rating these studies could receive under SIGN guidelines was $2+$, however, due to their retrospective design. Two studies received a rating of $2++[8,48]$, which was attributable to their prospective cohort design and high methodological standard. Four papers were rated 2- $[33,36,49,52]$ as the result of having a poor design and employing basic statistical analyses that posed a significant risk of confounding and gave a high probability that relationships between variables were not causal.

\section{Study population}

Publications emanated from a number of different countries, with most of the research being carried out in the US, UK or Canada. Recruitment settings varied across studies. In most cases, patient chart reviews were performed in hospital or rehabilitation centre settings, although two studies were based in the community [37,46]. Persons with lower limb amputations made up the entire study population in the majority of cases. In seven studies, 
however, a subsample of individuals with lower limb amputations was included as a comparison/control group for one $[5,44,50-52]$ or more $[39,45]$ other patient groups.

\section{Sample characteristics}

The number of persons with lower limb amputations taking part in each study ranged from as few as 8 [3] up to 2,922 [32]. There was great diversity across studies in terms of amputation etiology and level, mean age, and time since amputation. Participant selection criteria varied between studies. Most studies included persons with different amputation etiologies. In nine papers, however, only patients with amputations secondary to dysvascularity were selected for inclusion $[4,5,33,37,41,42,44,46,48]$. A study by Chiu and colleagues [35] included patients with dual disabilities of hemiplegia and amputation only. Many papers did not include persons with bilateral amputations in their samples. Five papers limited their investigations to persons aged either $60[7,46,48]$ or $65[34,37]$ years and over. The average amount of time elapsed since amputation varied from 19 days [4] up to almost 3 years [46] where reported, although this information was not provided in many instances.

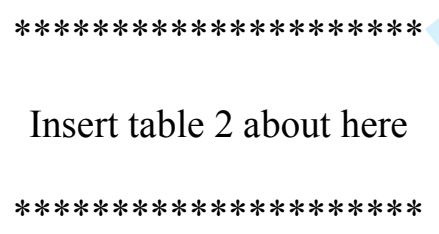

Assessment of cognitive functioning

Cognitive functioning was operationalised and measured in a number of ways across studies, as shown in table 2. Fifteen papers examined cognition as a categorical variable i.e. the presence or absence of dementia/cognitive impairment [33-38,40-45,49,53,54]. In twelve of these papers $[33,34,36-38,40-45,53]$, presence of dementia was ascertained from medical 
chart data. Five studies employed the Mini Mental State Examination (MMSE) [55] to indicate whether or not cognitive impairment was present $[3,38,41,42,52]$, although different cut-off scores were used to determine this. In two studies, the presence or absence of cognitive impairment was established through assessment by a psychologist $[35,54]$. Weiss and colleagues [49] failed to report how 'confusion' was assessed in their study.

Cognition was operationalised as one or more continuous variables in the remaining 15 studies, using a range of different assessment tools. A number of researchers used indices of overall cognitive functioning in their analyses [10,32,39,40,46,52], such as the FIM [56]. Other studies employed more detailed neuropsychological assessments to examine specific cognitive domains $[3,5,7,8,31,47,50]$. Among the tests of neuropsychological status most frequently used were the Repeatable Battery for the Assessment of Neuropsychological Status (RBANS) [57], which was employed in two studies [3,8], and the Addenbrookes Cognitive Examination (ACE) [58] or a revised version of this tool (ACE-R) [59], included in three papers $[3,8,31]$. Both of these measures assess different aspects of memory, language, verbal fluency, attention and concentration, visuospatial and perceptual abilities, as well as providing an overall index of cognition.

The timing of cognitive assessment varied widely between studies. In a study by Taylor et al. [43], for example, presence of dementia was assessed preoperatively, whereas in Bilodeau and associates' [46] community-based study, the average amount of time that had elapsed since amputation was 2.9 years.

\section{Cognitive status of persons with lower limb amputations}

A number of papers provided information on the prevalence of dementia and/or cognitive impairment among persons with lower limb amputations [3,31,33,34,36$38,40,44,45,48,54]$. The proportion of individuals diagnosed with dementia ranged from $5 \%$ 
[33] to $49.2 \%$ [44] across studies. Inconsistencies in the prevalence of cognitive impairment may be partly explained by the heterogeneity of samples in terms of characteristics such as amputation etiology and level, mean age, and the amount of time since amputation at which cognitive functioning was assessed. The range and quality of the different methods used to assess cognitive functioning, from medical chart review to more detailed neuropsychological assessment, is also likely to contribute towards the wide variation in cognition reported across studies. Eight papers reported dementia prevalence rates of over $10 \%$ among persons with lower limb amputations $[3,31,34,36-38,44,45]$, suggesting that the prevalence of dementia may indeed be higher in this patient group than in the population at large, for whom prevalence rates of $5-10 \%$ in those aged 65 years and above have generally been reported [12].

Three studies provided information on participants' performance in specific domains of cognitive functioning [3,5,31]. O’Neill and colleagues [3] reported RBANS subtest scores for eight persons with lower limb amputations, six of whom in the extremely low range of cognitive function on this measure. Mean scores for all domains assessed (immediate memory, visuospatial ability, language, attention, and delayed memory) were lower than those observed in the general population [57], particularly in the areas of memory and attention, with participants' cognitive profiles more closely resembling those of individuals with vascular dementia [60]. Donaghey and colleagues [31] presented mean ACE-R subtest scores for 30 individuals who had been deemed suitable candidates for prosthetic limb fitting. Eleven participants (42\%) scored below the cut-off score for dementia $(=82)$ on the ACE-R. On average, participants performed more poorly than a sample of individuals diagnosed with mild cognitive impairment on measures of attention and concentration, fluency, language, and visuospatial ability [59]. Phillips and colleagues [5] examined the nature and extent of cognitive deficits in 14 patients with amputations due to peripheral vascular disease (mean 
age $=67.4$ years), and compared them with a control group of 14 healthy persons without amputations (mean age $=69.9$ years). Participants in the amputation group had significantly slower psychomotor speed, as well as poorer problem solving and abstract reasoning abilities than those in the control group. There were also trends towards poorer performance on measures of visuospatial skills, concentration, and oral fluency among those with amputations. Together these studies indicate that, relative to the general population, persons with lower-extremity amputations secondary to PVD may be at increased risk of cognitive impairment, particularly in the areas of strategic problem-solving, reasoning abilities, and concentration.

\section{Associations between cognitive functioning and outcomes}

Twenty five of the thirty studies included in this review examined associations between cognition and various outcomes relevant to persons with lower limb amputations (see table 2), with most of the research focusing on aspects of prosthetic rehabilitation and subsequent functioning. Cognitive impairment was associated with failure to be successfully fitted with a prosthetic limb in six studies $[4,10,36,37,53,54]$. In persons who were successfully fitted, poorer cognitive functioning was related to less extensive use of the prosthesis $[43,46,54]$. Greater cognitive impairment was consistently associated with poorer mobility $[7,8,35,39,47]$ and loss of independence $[43,44,49]$. Other outcomes associated with cognition in this patient group include mortality [34,44], adherence to medical regimens [50], and the experience of falls $[38,40,45]$. With regard to specific areas of cognitive functioning examined, deficits in memory $[4,8,48]$ and executive functioning [8] were associated with reduced prosthetic use and poorer functional outcomes. It is important to bear in mind, however, that different measures of cognition and associated outcomes were used across studies, and no firm conclusions can thus be drawn regarding the findings observed. 
Furthermore, many of the studies included in this review are cross-sectional, and the direction of causality between cognitive functioning and associated outcomes can only be inferred.

A small number of prospective studies have been published, which provide more convincing evidence for a causal relationship between cognitive functioning and various outcomes $[8,47,48]$. A study by Hanspal and Fisher [47] examined the relationship between cognitive ability and mobility longitudinally in a sample of 32 patients with lower limb amputations, 20 of whom had significant comorbidities. Cognitive status at 2-4 weeks after amputation was found to predict $20 \%$ of the variance in mobility at $8-14$ months postamputation in the sample as a whole, and it accounted for $85 \%$ of the variance among patients without comorbid conditions. Schoppen and associates [48] conducted a prospective study of 46 patients with vascular amputations aged 60 years and older, and found that memory at two weeks after amputation, as assessed using the 15-word test [61], was a significant predictor of perceived health status at one year post-amputation, explaining $51 \%$ of the variance in this outcome along with 1-leg balance and the presence of comorbidities other than cardiopulmonary or diabetes. Memory was also a significant predictor of activity restriction at one year post-amputation, accounting for 33\% of variance in this outcome along with 1-leg balance. Lastly, a study by O'Neill and Evans [8] involved the administration of a battery of neuropsychological tests to 34 individuals during their first appointment at a prosthetic rehabilitation centre, with follow-up assessments of mobility and prosthesis use 6 months later. Visual memory was found to be a significant predictor of mobility as assessed using the the Locomotor Capabilities Index (LCI) [62], explaining 25\% of the variance in scores. The number of hours the prosthesis was worn daily was significantly predicted by verbal fluency, a measure of executive function. Finally, mobility grades [63] were significantly predicted by immediate verbal memory, which along with age, amputation level, and the presence of pain, accounted for $58 \%$ of the variance in this outcome. Overall, the 
findings of these studies suggest that cognitive deficit following amputation, particularly in the areas of memory and executive function, is predictive of greater functional limitations over time.

\section{Discussion}

The results above suggest that cognitive functioning is an issue deserving of further attention in the literature on persons with lower limb amputations, given the prevalence of cognitive impairment and associations with important outcomes. The heterogeneity of methodologies, sample characteristics and measurement tools employed precludes the pooling of data, however; any comparisons made between findings should be interpreted with caution. Another limitation of the research to date is the scarcity of longitudinal studies investigating cognitive functioning. Prospective research using valid and reliable measures is required to further explore the nature and extent of cognitive impairment among individuals with lower limb loss, and its value in predicting important outcomes in this patient group.

The findings of this review suggest that individuals with cognitive deficits may experience significant difficulties in learning how to use a prosthesis and in regaining mobility and independence in activities of daily living following lower limb amputation. These problems are often not appreciated until well into the rehabilitation process, potentially leading to wasted medical resources and significant effort on the part of both patient and rehabilitation team [4]. The administration of a neuropsychological screening assessment covering a wide variety of cognitive domains prior to embarking on a rehabilitation programme could offer many advantages to individuals with lower limb amputations. Understanding a patient's cognitive profile could help the rehabilitation team to better comprehend why he or she may be having difficulties mastering particular tasks of daily living and to adapt goals accordingly [13]. It could also facilitate the design of individualised 
programmes tailored to patients' specific abilities in order to minimise their cognitive weaknesses and maximise their cognitive strengths [5]. Moreover, the establishment of an evidence base to assist in distinguishing between persons with a good probability of mastering prosthesis use and those unlikely to achieve this goal may reduce the costs associated with unsuccessful attempts at prosthetic fitting, and allow for the development of interventions employing other types of adaptive equipment to maximise the independence of persons who are not suitable prosthetic candidates and thus enhance their participation and quality of life [8,37].

Ideally, each individual would undergo a detailed neuropsychological battery with well-established, validated and reliable measures. Studies of individuals with vascular cognitive impairment emphasise the need to assess a wide range of cognitive domains, with particular emphasis on executive functions (especially attention, working memory and setshifting), speed of information processing, and visuospatial abilities [20,64,65]. Specific assessments that are currently used clinically to screen for mild cognitive impairment or dementia in older adults include the Revised Cambridge Cognitive Examination (CAMCOGR) [66] and the Dementia Rating Scale [67]. As this review indicates, few studies have assessed the neuropsychological status of persons with lower limb amputations, and further research into the clinical validity and reliability of different neuropsychological assessment tools in this population is clearly required.

Due to time and resource constraints, however, individuals with amputations often have only limited access to clinical psychologists or neuropsychologists during their rehabilitation programme, and the administration of detailed clinical assessments is not always feasible. A number of standardised and validated cognitive screening tools that can be administered by other rehabilitation team members including medics, nurses and occupational therapists are available. They provide an overview of a number of cognitive 
domains including orientation, memory, attention and executive function, visuospatial abilities, and language. These screening tools are easy to administer and can be completed in 15-30 minutes. Examples include the RBANS and ACE-R, both of which have recently been successfully administered to individuals with lower limb amputations [8,31]. Other assessments that may be suitable for this purpose include the the Frontal Assessment Battery (FAB) [68] and the Montreal Cognitive Assessment (MoCA) [69], which in a recent study [70] demonstrated greater sensitivity to the cognitive abnormalities associated with vascular mild cognitive impairment than the widely used MMSE [55]. It is important to bear in mind that the timing of cognitive assessment may have a significant influence on performance, as individuals who undergo major surgery often experience transitory problems in memory and cognition in the days and weeks following the operation [71].

Although cognitive impairment appears to predict difficulties in regaining mobility and independence in activities of daily living following lower limb amputation, even those with significant impairment are likely to benefit from structured rehabilitation programmes designed to help them obtain and maintain their highest level of functioning [4]. In a mixed sample of older adults participating in a rehabilitation programme, for example, Resnick and Daly [72] found that although individuals with cognitive impairment had lower functional performance at each testing period, they improved functionally over the course of their rehabilitation programme and maintained their discharge level of functioning at one year follow-up. It should not be assumed, therefore, that presence of cognitive impairment is reason enough in itself to exclude patients from participating in rehabilitation.

More research is required to explore the impact that different degrees of cognitive deficit and areas affected have on functioning in this patient group, and to develop interventions that can facilitate participation in rehabilitation for patients with such impairments [72]. Indeed, a range of different strategies have been developed to teach new 
information effectively to individuals with cognitive impairments, including 'errorless learning' training techniques and the use of assistive technologies such as prompting devices, both of which were successfully piloted in a sample of persons with lower limb amputations $[3,31]$. Such strategies may be usefully applied in rehabilitation settings to improve the chances of persons with cognitive impairment regaining their independence and attaining optimal mobility, while simultaneously reducing the amount of time and associated costs required to achieve these outcomes.

In conclusion, the findings of this review suggest that cognitive impairment is relatively common among individuals with lower limb amputations, and can significantly impact on functional outcomes . Further research into the neuropsychological profiles of this patient group is clearly needed. Cognitive assessments examining a wide array of domains, particularly those affected by vascular cognitive impairment (i.e. executive function, speed of information processing, visuospatial functioning and attention), could potentially improve service provision for individuals with limb loss. Cognitive dysfunction often goes unnoticed until well into the rehabilitation process, resulting in poor use of time, effort and medical resources, and may represent a missed opportunity for such patients to achieve mobility through other means, such as wheelchair use [9]. Assessing the cognitive abilities of patients early in the rehabilitation process would enable medical staff to determine their suitability for prosthetic or wheelchair rehabilitation, to ascertain appropriate and realistic goals for rehabilitation, and to tailor the rehabilitation programme to patients' strengths so that maximal mobility and independence is achieved. 


\section{Declaration of Interest}

The authors report no conflicts of interest. The authors alone are responsible for the content and writing of the paper. 
1. Horgan O, MacLachlan M. Psychosocial adjustment to lower-limb amputation: A review. Disabil Rehabil 2004;26(14):837-50.

2. van Velzen JM, van Bennekom CAM, Polomski W, Slootman JR, van der Woude LHV, Houdijk H. Physical capacity and walking ability after lower limb amputation: A systematic review. Clin Rehabil 2006;20(11):999-1016.

3. O'Neill B, Moran K, Gillespie A. Scaffolding rehabilitation behaviour using a voicemediated assistive technology for cognition. Neuropsych Rehabil 2010;20(4):509-27.

4. Larner S, Van Ross E, Hale C. Do psychological measures predict the ability of lower limb amputees to learn to use a prosthesis? Clin Rehabil 2003;17(5):493-8.

5. Phillips NA, Kole CC, Kirby RL. Neuropsychological function in peripheral vascular disease amputee patients. Arch Phys Med Rehabil 1993;74(12):1309-14.

6. Fuhrer MJ, Keith RA. Facilitating patient learning during medical rehabilitation: A research agenda. Am J Phys Med Rehab 1998;77(6):557-61.

7. Hanspal RS, Fisher K. Assessment of cognitive and psychomotor function and rehabilitation of elderly people with prostheses. Brit Med J 1991;302:940.

8. O'Neill BF, Evans JJ. Memory and executive function predict mobility rehabilitation outcome after lower-limb amputation. Disabil Rehabil 2009;31(13):1083-91. 
9. O'Neill BF. Cognition and mobility rehabilitation following lower limb amputation. In: P. Gallagher, D. Desmond, M. MacLachlan, editors. Psychoprosthetics. London: Springer; 2008. p 53-65.

10. Kurichi JE, Kwong PL, Reker DM, Bates BE, Marshall CR, Stineman MG. Clinical factors associated with prescription of a prosthetic limb in elderly veterans. J Am Geriatr Soc 2007;55(6):900-6.

11. Aguero-Torres HF, L., Guo Z, Viitanen M, von Strauss E, Winblad B. Dementia is the major cause of functional dependence in the elderly: 3-year follow-up data from a population-based study. Am J Public Health 1998;88(10):1452-6.

12. Rafnsson SB, Deary IJ, Fowkes FGR. Peripheral arterial disease and cognitive function. Vasc Med 2009;14:51-61.

13. Stephens S, Kenny RA, Rowan E, Kalaria RN, Bradbury M, Pearce R, Wesnes K, Ballard CG. Association between mild vascular cognitive impairment and impaired activities of daily living in older stroke survivors without dementia. J Am Geriatr Soc 2005;53(1):103-7.

14. Nowygrod R, Egorova N, Greco G, Anderson P, Gelijns A, Moskowitz A, McKinsey J, Morrissey N, Kent KC. Trends, complications, and mortality in peripheral vascular surgery. J Vasc Surg 2006;43(2):205-16.

15. National Amputee Statistical Database. The amputee statistical database for the United Kingdom 2006/07. Edinburgh: Information Services Division, NHS Scotland; 2009. 41 p. 
16. Park D, Schwarz N. Cognitive aging: A primer. Philadelphia, PA: Psychology Press; 2000. 312 p.

17. Andrews KL. Rehabilitation in limb deficiency 3: The geriatric amputee. Arch Phys Med Rehabil 1996;77(3S):14-7.

18. [NLLIC] National Limb Loss Information Center. 2008. Amputation statistics by cause: Limb loss in the United States. $<\underline{\text { http:} / / w w w . a m p u t e e-~}$ coalition.org/fact_sheets/amp_stats_cause.html>. Accessed 2009 Feb 2.

19. Rotkiewicz-Piorun AM, Al Snih S, Raji MA, Kuo YF, Markides KS. Cognitive decline in older Mexican Americans with diabetes. J Natl Med Assoc 2006;98(11):1840-7.

20. O'Brien JT, Erkinjuntti T, Reisberg B, Roman G, Sawada T, Pantoni L, Bowler JV, Ballard C, DeCarli C, Gorelick PB, et al. Vascular cognitive impairment. Lancet Neurol 2003;2(2):89-98.

21. Desmond DW. The neuropsychology of vascular cognitive impairment: Is there a specific cognitive deficit? J Neurol Sci 2004;226(1-2):3-7.

22. Rockwood K, Wentzel C, Hachinski V, Hogan DB, MacKnight C, McDowell I. Prevalence and outcomes of vascular cognitive impairment. Neurology 2000;54(2):44751.

23. Waldstein SR, Tankard CF, Maier KJ, Pelletier JR, Snow J, Gardner AW, Macko R, Katzel LI. Peripheral arterial disease and cognitive function. Psychosom Med 2003;65(5):757-63. 
24. Fosse S, Hartemann-Heurtier A, Jacqueminet S, Ha Van G, Grimaldi A, Fagot-Campagna A. Incidence and characteristics of lower limb amputations in people with diabetes. Diabetic Med 2009;26(4):391-6.

25. Strachan MW, Deary IJ, Ewing FM, Frier BM. Is type II diabetes associated with an increased risk of cognitive dysfunction? A critical review of published studies. Diabetes Care 1997;20(3):438-45.

26. Leibson CL, Rocca WA, Hanson VA, Cha R, Kokmen E, O'Brien PC, Palumbo PJ. Risk of dementia among persons with diabetes mellitus: A population-based cohort study. Am J Epidemiol 1997;145(4):301-8.

27. Verdelho A, Madureira S, Ferro JM, Basile AM, Chabriat H, Erkinjuntti T, Fazekas F, Hennerici M, O’Brien J, Pantoni L. Differential impact of cerebral white matter changes, diabetes, hypertension and stroke on cognitive performance among non-disabled elderly. The LADIS study. J Neurol Neurosur Ps 2007;78(12):1325-30.

28. Sansam K, Neumann V, O'Connor R, Bhakta B. Predicting walking ability following lower limb amputation: A systematic review of the literature. J Rehabil Med 2009;41(8):593-603.

29. Cecchino NJ. Google Scholar. J Med Lib Assoc 2010;98(4):320-1.

30. [SIGN] Scottish Intercollegiate Guidelines Network. 2008. SIGN 50 - A guideline developer's handbook. Scottish Intercollegiate Guidelines Network. <www.sign.ac.uk/pdf/sign50/pdf. Accessed 2011 Dec 14. 
31. Donaghey CL, McMillan TM, O'Neill B. Errorless learning is superior to trial and error when learning a practical skill in rehabilitation: A randomized controlled trial. Clin Rehabil 2010;24(3):195-201.

32. Bates BE, Kwong PL, Kurichi JE, Bidelspach DE, Reker DM, Maislin G, Xie D, Stineman M. Factors influencing decisions to admit patients to Veterans Affairs specialized rehabilitation units after lower-extremity amputation. Arch Phys Med Rehabil 2009;90(12):2012-8.

33. Campbell WB, Marriott S, Eve R, Mapson E, Sexton S, Thompson JF. Factors influencing the early outcome of major lower limb amputation for vascular disease. Ann R Coll Surg Engl 2001;83(5):309-14.

34. Carmona GA, Hoffmeyer P, Herrmann FR, Vaucher J, Tschopp O, Lacraz A, Vischer UM. Major lower limb amputations in the elderly observed over ten years: The role of diabetes and peripheral arterial disease. Diabetes Metab 2005;31(5):449-54.

35. Chiu CC, Chen CE, Wang TG, Lin MC, Lien I. Influencing factors and ambulation outcome in patients with dual disabilities of hemiplegia and amputation. Arch Phys Med Rehabil 2000;81(1):14-7.

36. Couch NP, David JK, Tilney NL, Crane C. Natural history of the leg amputee. Am J Surg 1977;133(4):469-73.

37. Fletcher DD, Andrews KL, Butters MA, Jacobsen SJ, Rowland CM, Hallett JW. Rehabilitation of the geriatric vascular amputee patient: A population-based study. Arch Phys Med Rehabil 2001;82(6):776-9. 
38. Gooday HM, Hunter J. Preventing falls and stump injuries in lower limb amputees during inpatient rehabilitation: Completion of the audit cycle. Clin Rehabil 2004;18(4):379-90.

39. Heinemann AW, Linacre JM, Wright BD, Hamilton BB, Granger C. Prediction of rehabilitation outcomes with disability measures. Arch Phys Med Rehabil $1994 ; 75(2): 133-43$.

40. Pauley T, Devlin M, Heslin K. Falls sustained during inpatient rehabilitation after lower limb amputation: Prevalence and predictors. Am J Phys Med Rehab 2006;85(6):521-32.

41. Remes L, Isoaho R, Vahlberg T, Hiekkanen H, Korhonen K, Viitanen M, Rautava P. Major lower extremity amputation in elderly patients with peripheral arterial disease: Incidence and survival rates. Aging Clin Exp Res 2008;20(5):385-93.

42. Remes L, Isoaho R, Vahlberg T, Viitanen M, Rautava P. Predictors for institutionalization and prosthetic ambulation after major lower extremity amputation during an eight-year follow-up. Aging Clin Exp Res 2009;21(2):129-35.

43. Taylor SM, Kalbaugh CA, Blackhurst DW, Hamontree SE, Cull DL, Messich HS, Robertson RT, Langan EM, York JW, Carsten CG. Preoperative clinical factors predict postoperative functional outcomes after major lower limb amputation: An analysis of 553 consecutive patients. J Vasc Surg 2005;42(2):227-34.

44. Taylor SM, Kalbaugh CA, Blackhurst DW, Kellicut DC, Langan III EM, Youkey JR. A comparison of percutaneous transluminal angioplasty versus amputation for critical limb ischemia in patients unsuitable for open surgery. J Vasc Surg 2007;45(2):304-10. 
45. Yu JC, Lam K, Nettel-Aguirre A, Donald M, Dukelow S. Incidence and risk factors of falling in the postoperative lower limb amputee while on the surgical ward. PM\&R 2010;2(10):926-34.

46. Bilodeau S, Hébert R, Desrosiers J. Lower limb prosthesis utilisation by elderly amputees. Prosthet Orthot Int 2000;24(2):126-32.

47. Hanspal RS, Fisher K. Prediction of achieved mobility in prosthetic rehabilitation of the elderly using cognitive and psychomotor assessment. Int J Rehabil Res 1997;20(3):3158.

48. Schoppen T, Boonstra A, Groothoff JW, de Vries J, Goeken LN, Eisma WH. Physical, mental, and social predictors of functional outcome in unilateral lower-limb amputees. Arch Phys Med Rehabil 2003;84(6):803-11.

49. Weiss GN, Gorton TA, Read RC, Neal LA. Outcomes of lower extremity amputations. J Am Geriatr Soc 1990;38(8):877-83.

50. Coetzee N, Andrewes D, Khan F, Hale T, Jenkins L, Lincoln N, Disler P. Predicting compliance with treatment following stroke: A new model of adherence following rehabilitation. Brain Impair 2008;9(2):122-39.

51. Wang PL, Kaplan JR, Rogers EJ. Memory functioning in hemiplegics: A neuropsychological analysis of the wechsler memory scale. Arch Phys Med Rehabil $1975 ; 56(12): 517-21$.

52. Willrich A, Pinzur M, McNeil M, Juknelis D, Lavery L. Health related quality of life, cognitive function, and depression in diabetic patients with foot ulcer or amputation. A preliminary study. Foot Ankle Int 2005;26(2):128-34. 
53. Aftabuddin M, Islam N, Jafar MAHM, Haque I. The status of lower-limb amputation in Bangladesh: A 6-year review. Surg Today 1997;27(2):130-4.

54. Pinzur MS, Graham G, Osterman H. Psychologic testing in amputation rehabilitation. Clin Orthop Relat Res 1988;229:236-40.

55. Folstein MF, Folstein SE, McHugh PR. "Mini-Mental State": A practical method for grading the cognitive state of patients for the clinician. J Psychiatr Res 1975;12(3):18998.

56. Keith RA, Granger CV, Hamilton BB, Sherwin FS. The Functional Independence Measure: A new tool for rehabilitation. Adv Clin Rehabil 1987;1:6-18.

57. Randolph C, Tierney MC, Mohr E, Chase TN. The Repeatable Battery for the Assessment of Neuropsychological Status (RBANS): Preliminary clinical validity. J Clin Exp Neuropsyc 1998;20(3):310-9.

58. Mathuranath PS, Nestor PJ, Berrios GE, Rakowicz W, Hodges JR. A brief cognitive test battery to differentiate Alzheimer's disease and frontotemporal dementia. Neurology 2000;55(11):1613-20.

59. Mioshi E, Dawson K, Mitchell J, Arnold R, Hodges JR. The Addenbrooke's Cognitive Examination Revised (ACE - R): A brief cognitive test battery for dementia screening. Int J Geriatr Psychiatry 2006;21(11):1078-85.

60. Fink J, McCrea M, Randolph C. Neuropsychological differentiation of vascular dementia and Alzheimer's disease: A neurocognitive profile approach using a short battery. J Int Neuropsych Soc 1998;4:30. 
61. Heslinga H, Van der Burg W, Saan RJ. De nieuwe 15-woordentest A en B in een gezonde populatie. Groningen (Netherlands): Rijksuniv Groningen; 1983.

62. Gauthier-Gagnon C, Grise MC, Lepage Y. The Locomotor Capabilities Index: Content validity. J Rehab Outcome Meas 1998;2(4):40-6.

63. Ryall N, Eyres S, Neumann V, Bhakta B, Tennant A. The SIGAM mobility grades: A new population-specific measure for lower limb amputees. Disabil Rehabil $2003 ; 25(15): 833-44$.

64. Hachinski V, Iadecola C, Petersen RC, Breteler MM, Nyenhuis DL, Black SE, Powers WJ, DeCarli C, Merino JG, Kalaria RN. National Institute of Neurological Disorders and Stroke-Canadian Stroke Network vascular cognitive impairment harmonization standards. Stroke 2006;37(9):2220-41.

65. Nordlund A, Rolstad S, Klang O, Lind K, Hansen S, Wallin A. Cognitive profiles of mild cognitive impairment with and without vascular disease. Neuropsychology 2007;21(6):706-12.

66. Roth M, Huppert F, Mountjoy C, Tym E. The Cambridge Examination for Mental Disorders of the Elderly - Revised. Cambridge: Cambridge University Press; 1999. .

67. Mattis S. Dementia rating scale. Odessa, FL: Psychological Assessment Resources; 1988.

68. Dubois B, Slachevsky A, Litvan I, Pillon B. The FAB: A frontal assessment battery at bedside. Neurology 2000;55(11):1621-8. 
69. Nasreddine ZS, Phillips NA, Bédirian V, Charbonneau S, Whitehead V, Collin I, Cummings JL, Chertkow H. The Montreal Cognitive Assessment, MoCA: A brief screening tool for mild cognitive impairment. J Am Geriatr Soc 2005;53(4):695-9.

70. Pendlebury ST, Cuthbertson FC, Welch SJV, Mehta Z, Rothwell PM. Underestimation of cognitive impairment by Mini-Mental State Examination versus the Montreal Cognitive Assessment in patients with transient ischemic attack and stroke: A population-based study. Stroke 2010;41(6):1290-3.

71. Tsai TL, Sands LP, Leung JM. An update on postoperative cognitive dysfunction. Adv Anesth 2010;28(1):269-84.

72. Resnick B, Daly MP. The effect of cognitive status on outcomes following rehabilitation. Fam Med 1997;29(6):400-5. 
Table 1. Overview of studies included in literature review: description of study design, recruitment setting, participants, and methodological quality.

\begin{tabular}{|c|c|c|c|c|c|c|c|c|c|c|}
\hline $\begin{array}{l}\text { Author } \\
\text { (year of } \\
\text { publication) }\end{array}$ & Country & Study design & $\begin{array}{l}\text { Recruitment } \\
\text { setting }\end{array}$ & Participants & Gender & $\begin{array}{l}\text { Amputation } \\
\text { level }\end{array}$ & $\begin{array}{l}\text { Amputation } \\
\text { etiology }\end{array}$ & Mean age & $\begin{array}{l}\text { Mean time since } \\
\text { amputation }\end{array}$ & $\begin{array}{l}\text { SIGN } \\
\text { evidence } \\
\text { level }\end{array}$ \\
\hline $\begin{array}{l}\text { Aftabuddin et } \\
\text { al. (1997) }\end{array}$ & Bangladesh & $\begin{array}{l}\text { Cross- } \\
\text { sectional (non- } \\
\text { analytic) }\end{array}$ & $\begin{array}{l}\text { Hospital (chart } \\
\text { review) }\end{array}$ & $\begin{array}{l}450 \text { persons who underwent } \\
\text { single lower limb amputation } \\
\text { between July } 1982 \text { and June } \\
1987\end{array}$ & $\begin{array}{l}75 \% \text { male } \\
25 \% \text { female }\end{array}$ & $\begin{array}{l}38 \% \text { BK } \\
62 \% \text { AK }\end{array}$ & $\begin{array}{l}81 \% \text { vascular } \\
\text { disease } \\
9 \% \text { other reasons } \\
\text { (diabetes, infection, } \\
\text { malignancy) }\end{array}$ & $\begin{array}{l}\text { Not reported } \\
(84 \%<60 \\
\text { years })\end{array}$ & Not reported & 3 \\
\hline $\begin{array}{l}\text { Bates et al. } \\
\text { (2009) }\end{array}$ & USA & $\begin{array}{l}\text { Retrospective } \\
\text { cohort }\end{array}$ & $\begin{array}{l}\text { All Veterans Affairs } \\
\text { Medical Centres } \\
\text { (VAMCs) in the US } \\
\text { (chart review) }\end{array}$ & $\begin{array}{l}2922 \text { persons who underwent } \\
\text { major lower-extremity hip to } \\
\text { ankle amputation discharged } \\
\text { from acute hospital between } \\
1 \text { October } 2002 \text { and } 30 \\
\text { September } 2004\end{array}$ & $\begin{array}{l}99 \% \text { male } \\
1 \% \text { female }\end{array}$ & $\begin{array}{l}58 \% \mathrm{BK} \\
34 \% \text { AK } \\
8 \% \text { bilateral }\end{array}$ & $\begin{array}{l}\text { Most patients had } \\
\text { multiple } \\
\text { contributing } \\
\text { etiologies, no } \\
\text { separate figures } \\
\text { provided (88\% had } \\
\text { PVD) }\end{array}$ & 65.9 years & $\begin{array}{l}8.4 \text { days from } \\
\text { admission to } \\
\text { surgery } \\
7.95 \text { days from } \\
\text { surgery to initial } \\
\text { rehabilitation } \\
\text { assessment }\end{array}$ & $2+$ \\
\hline $\begin{array}{l}\text { Bilodeau et } \\
\text { al. (2000) }\end{array}$ & Canada & $\begin{array}{l}\text { Cross- } \\
\text { sectional } \\
\text { (analytic) }\end{array}$ & $\begin{array}{l}\text { Community } \\
\text { (Sherbrooke, semi- } \\
\text { urban area with } \\
\text { population of } \\
250,000 \text { ) }\end{array}$ & $\begin{array}{l}65 \text { persons aged } 60 \text { years or } \\
\text { over currently living at home } \\
\text { who underwent unilateral } \\
\text { amputations of vascular } \\
\text { etiology between } 1 \text { April } \\
1987 \text { and } 31 \text { December } 1992 \\
\text { in one of } 4 \text { hospitals in } \\
\text { Sherbrooke and received a } \\
\text { prosthesis }\end{array}$ & $\begin{array}{l}80 \% \text { male } \\
20 \% \text { female }\end{array}$ & $\begin{array}{l}52.3 \% \mathrm{BK} \\
47.8 \% \mathrm{AK}\end{array}$ & $\begin{array}{l}100 \% \text { of vascular } \\
\text { origin }\end{array}$ & 71.6 years & 2.9 years & $2+$ \\
\hline $\begin{array}{l}\text { Campbell et } \\
\text { al. (2001) }\end{array}$ & UK & $\begin{array}{l}\text { Retrospective } \\
\text { cohort }\end{array}$ & $\begin{array}{l}\text { Hospital (chart } \\
\text { review) }\end{array}$ & $\begin{array}{l}312 \text { persons who underwent } \\
349 \text { primary major lower } \\
\text { limb amputations for } \\
\text { vascular disease between } \\
1992 \text { and } 1998\end{array}$ & $\begin{array}{l}57 \% \text { male } \\
43 \% \text { female }\end{array}$ & $\begin{array}{l}55 \% \text { BK } \\
35 \% \text { AK } \\
10 \% \text { Gritti } \\
\text { Stokes } \\
0.3 \% \text { hip } \\
\text { disarticulation }\end{array}$ & $\begin{array}{l}\text { 100\% vascular } \\
\text { disease }\end{array}$ & $\begin{array}{l}76 \text { years } \\
\text { (median age) }\end{array}$ & Not reported & $2-$ \\
\hline $\begin{array}{l}\text { Carmona et } \\
\text { al. (2005) }\end{array}$ & Switzerland & $\begin{array}{l}\text { Retrospective } \\
\text { cohort }\end{array}$ & $\begin{array}{l}\text { Hospital (chart } \\
\text { review) }\end{array}$ & $\begin{array}{l}209 \text { persons aged over } 65 \\
\text { years who underwent } 262 \\
\text { major lower limb } \\
\text { amputations between } 1 \\
\text { January } 1990 \text { and } 31 \\
\text { December } 1999\end{array}$ & $\begin{array}{l}55.5 \% \text { male } \\
44.5 \% \\
\text { female }\end{array}$ & $\begin{array}{l}47 \% \text { BK } \\
30.2 \% \text { through- } \\
\text { knee } \\
22.5 \% \text { AK }\end{array}$ & $\begin{array}{l}94.3 \% \text { arterial } \\
\text { disorders } \\
5.7 \% \text { non-arterial } \\
\text { conditions } \\
\text { (tumours, trauma, } \\
\text { osteomyelitis, and } \\
\text { others) }\end{array}$ & 78 years & Not reported & $2+$ \\
\hline $\begin{array}{l}\text { Chiu et al. } \\
(2000)\end{array}$ & Taiwan & $\begin{array}{l}\text { Retrospective } \\
\text { cohort }\end{array}$ & $\begin{array}{l}\text { Rehabilitation centre } \\
\text { of a university } \\
\text { hospital (chart }\end{array}$ & $\begin{array}{l}23 \text { persons with dual } \\
\text { disabilities of lower limb } \\
\text { amputation and hemiplegia }\end{array}$ & $\begin{array}{l}70 \% \text { male } \\
30 \% \text { female }\end{array}$ & $\begin{array}{l}65 \% \mathrm{BK} \\
35 \% \mathrm{AK}\end{array}$ & $\begin{array}{l}52 \% \text { PVD } \\
48 \% \text { diabetes }\end{array}$ & 65.5 years & Not reported & $2+$ \\
\hline
\end{tabular}

URL: http:/mc.manuscriptcentral.com/dandr Email: davemuller@suffolk.ac.uk 


\begin{tabular}{|c|c|c|c|c|c|c|c|c|c|c|}
\hline & & & review) & $\begin{array}{l}\text { admitted to rehabilitation } \\
\text { department between } 1984 \\
\text { and } 1994\end{array}$ & & & & & & \\
\hline $\begin{array}{l}\text { Coetzee et al. } \\
\text { (2008) }\end{array}$ & Australia & Case-control & Rehabilitation centre & $\begin{array}{l}26 \text { stroke patients (cases) and } \\
30 \text { amputee patients } \\
\text { (controls) who completed an } \\
\text { inpatient rehabilitation } \\
\text { programme }\end{array}$ & $\begin{array}{l}73 \% \text { male } \\
27 \% \text { female } \\
\text { (amputation } \\
\text { group only) }\end{array}$ & $\begin{array}{l}23 \% \mathrm{BK} \\
50 \% \text { AK } \\
3 \% \text { through-knee } \\
3 \% \\
\text { transmetatarsal } \\
3 \% \\
\text { transtemporal } \\
10 \% \text { bilateral }\end{array}$ & $\begin{array}{l}73 \% \text { cardiovascular } \\
27 \% \text { trauma }\end{array}$ & $\begin{array}{l}63.7 \text { years } \\
\text { (amputation } \\
\text { group only) }\end{array}$ & Not reported & $2+$ \\
\hline $\begin{array}{l}\text { Couch et al. } \\
\text { (1977) }\end{array}$ & USA & $\begin{array}{l}\text { Retrospective } \\
\text { cohort }\end{array}$ & $\begin{array}{l}\text { Hospital (chart } \\
\text { review) }\end{array}$ & $\begin{array}{l}173 \text { persons who underwent } \\
242 \text { major lower limb } \\
\text { amputations between } 1963 \\
\text { and } 1974\end{array}$ & $\begin{array}{l}51 \% \text { male } \\
49 \% \text { female }\end{array}$ & $\begin{array}{l}49 \% \text { BK } \\
51 \% \text { AK } \\
\text { (doesn't report } \\
\text { number of } \\
\text { bilateral } \\
\text { amputations) }\end{array}$ & Not reported & 60 years & 3.5 years & $2-$ \\
\hline $\begin{array}{l}\text { Donaghey et } \\
\text { al. (2010) }\end{array}$ & UK & $\begin{array}{l}\text { Randomised } \\
\text { controlled trial }\end{array}$ & $\begin{array}{l}\text { Regional limb- } \\
\text { fitting clinic }\end{array}$ & $\begin{array}{l}30 \text { persons with transtibial } \\
\text { amputations who had not yet } \\
\text { been fitted with a prosthetic } \\
\text { limb (15 in intervention } \\
\text { group, } 15 \text { in control group) }\end{array}$ & $\begin{array}{l}70 \% \text { male } \\
30 \% \text { female }\end{array}$ & $100 \% \mathrm{BK}$ & $\begin{array}{l}66.7 \% \text { PVD } \\
\text { secondary to } \\
\text { diabetes mellitus } \\
23.3 \% \text { PVD } \\
\text { without } \\
\text { comorbidity }\end{array}$ & 64 years & $\begin{array}{l}7 \text { weeks (median } \\
\text { time between } \\
\text { amputation and } \\
\text { limb fitting) }\end{array}$ & $1++$ \\
\hline $\begin{array}{l}\text { Fletcher et al. } \\
\text { (2001) }\end{array}$ & USA & $\begin{array}{l}\text { Retrospective } \\
\text { cohort }\end{array}$ & $\begin{array}{l}\text { General community } \\
\text { (Olmsted County, } \\
\text { Minnesota, USA) }\end{array}$ & $\begin{array}{l}199 \text { residents aged over } 65 \\
\text { years who had a major lower } \\
\text { limb amputation for } \\
\text { peripheral vascular disease } \\
\text { between } 1974 \text { and } 1995\end{array}$ & Not reported & $\begin{array}{l}64 \% \text { BK } \\
4.5 \% \text { knee } \\
\text { disarticulation } \\
31 \% \text { AK } \\
0.5 \% \text { hip } \\
\text { disarticulation } \\
\end{array}$ & $\begin{array}{l}100 \% \\
\text { arteriosclerotic } \\
\text { vascular disease }\end{array}$ & $\begin{array}{l}79.7 \text { years } \\
\text { (median age) }\end{array}$ & Not reported & $2+$ \\
\hline $\begin{array}{l}\text { Gooday \& } \\
\text { Hunter } \\
\text { (2004) }\end{array}$ & UK & $\begin{array}{l}\text { 3-phase study } \\
\text { Phase 1: } \\
\text { retrospective } \\
\text { cohort } \\
\text { Phase 2: } \\
\text { prospective } \\
\text { cohort } \\
\text { Phase 3: } \\
\text { prospective } \\
\text { cohort }\end{array}$ & $\begin{array}{l}\text { 20-bedded inpatient } \\
\text { rehabilitation unit } \\
\text { for amputees }\end{array}$ & $\begin{array}{l}\text { Phase 1: } 193 \text { persons with } \\
\text { lower limb amputations who } \\
\text { had an accident during their } \\
\text { inpatient stay between } 1 \\
\text { April } 1996 \text { and } 31 \text { October } \\
1998 \\
\text { Phase 2: } 113 \text { persons with } \\
\text { lower limb amputations } \\
\text { admitted to the unit for } \\
\text { rehabilitation from 1 March } \\
\text { 1999 to } 30 \text { June } 2000 \\
\text { Phase 3: } 62 \text { persons with } \\
\text { lower limb amputations }\end{array}$ & $\begin{array}{l}\text { Phase 1: not } \\
\text { reported } \\
\text { Phase 2: 66\% } \\
\text { male } \\
34 \% \text { female } \\
\text { Phase 3: } 68 \% \\
\text { male } \\
\text { 32\% female }\end{array}$ & $\begin{array}{l}\text { Phase 1: not } \\
\text { reported } \\
\text { Phase 2: } \\
55 \% \text { BK, } \\
45 \% \text { AK } \\
\\
\text { Phase 3: } \\
48 \% \text { BK } \\
52 \% \text { AK }\end{array}$ & $\begin{array}{l}\text { Phase 1: not } \\
\text { reported } \\
\text { Phase 2: } \\
55 \% \\
\text { arteriosclerosis } \\
31 \% \text { diabetes } \\
4 \% \text { trauma } \\
4 \% \text { infection } \\
3 \% \text { infection plus } \\
\text { PVD } \\
4 \% \text { other } \\
\text { Phase 3: } \\
40 \% \\
\end{array}$ & $\begin{array}{l}\text { Phase 1: not } \\
\text { reported } \\
\text { Phase 2: } \\
70 \text { years } \\
\text { Phase 3: } \\
64.4 \text { years }\end{array}$ & Not reported & $2+$ \\
\hline
\end{tabular}

URL: http:/mc.manuscriptcentral.com/dandr Email: davemuller@suffolk.ac.uk 


\begin{tabular}{|c|c|c|c|c|c|c|c|c|c|c|}
\hline & & & & $\begin{array}{l}\text { admitted to the unit and } \\
\text { discharged between } 6 \\
\text { February } 2002 \text { and } 6 \\
\text { November } 2002\end{array}$ & & & $\begin{array}{l}\text { arteriosclerosis } \\
35 \% \text { diabetes } \\
3 \% \text { trauma } \\
5 \% \text { infection } \\
8 \% \text { infection plus } \\
\text { PVD } \\
8 \% \text { other }\end{array}$ & & & \\
\hline $\begin{array}{l}\text { Hanspal \& } \\
\text { Fisher (1991) }\end{array}$ & UK & $\begin{array}{l}\text { Cross- } \\
\text { sectional } \\
\text { (analytic) }\end{array}$ & $\begin{array}{l}\text { Regional } \\
\text { disablement services } \\
\text { centre }\end{array}$ & $\begin{array}{l}100 \text { persons aged over } 60 \\
\text { years with unilateral major } \\
\text { lower limb amputations } \\
\text { attending a limb fitting clinic } \\
\text { for maintenance of the } \\
\text { prosthesis }\end{array}$ & $\begin{array}{l}31 \% \text { male } \\
69 \% \text { female }\end{array}$ & $\begin{array}{l}49 \% \mathrm{BK} \\
51 \% \mathrm{AK}\end{array}$ & Not reported & 72.4 years & Not reported & $2+$ \\
\hline $\begin{array}{l}\text { Hanspal \& } \\
\text { Fisher (1997) }\end{array}$ & UK & $\begin{array}{l}\begin{array}{l}\text { Prospective } \\
\text { cohort }\end{array} \\
\mathrm{T} 1=2-4 \\
\text { weeks post- } \\
\text { amputation } \\
\mathrm{T} 2=8-14 \\
\text { months post- } \\
\text { amputation }\end{array}$ & $\begin{array}{l}\text { Regional } \\
\text { disablement services } \\
\text { centre }\end{array}$ & $\begin{array}{l}32 \text { persons with major lower } \\
\text { limb amputations }\end{array}$ & $\begin{array}{l}56 \% \text { male } \\
44 \% \text { female }\end{array}$ & $\begin{array}{l}47 \% \mathrm{BK} \\
53 \% \mathrm{AK}\end{array}$ & Not reported & 66.4 years & Not reported & $2+$ \\
\hline $\begin{array}{l}\text { Heinemann } \\
\text { et al. (1994) }\end{array}$ & USA & $\begin{array}{l}\text { Retrospective } \\
\text { cohort }\end{array}$ & $\begin{array}{l}46 \text { rehabilitation } \\
\text { units within acute } \\
\text { hospitals and } 26 \\
\text { freestanding } \\
\text { rehabilitation } \\
\text { hospitals (chart } \\
\text { review) }\end{array}$ & $\begin{array}{l}27,669 \text { persons with different } \\
\text { types of impairments } \\
\text { admitted to an inpatient } \\
\text { rehabilitation facility }(1,400 \\
\text { individuals had undergone } \\
\text { major lower limb } \\
\text { amputation) }\end{array}$ & $\begin{array}{l}60.9 \% \text { male } \\
39.1 \% \\
\text { female } \\
\text { (amputation } \\
\text { group only) }\end{array}$ & Not reported & Not reported & $\begin{array}{l}66.9 \text { years } \\
\text { (amputation } \\
\text { group only) }\end{array}$ & Not reported & $2+$ \\
\hline $\begin{array}{l}\text { Kurichi et al. } \\
\text { (2007) }\end{array}$ & USA & $\begin{array}{l}\text { Retrospective } \\
\text { cohort }\end{array}$ & $\begin{array}{l}\text { All VAMCs in US } \\
\text { (chart review) }\end{array}$ & $\begin{array}{l}2,375 \text { veterans with major } \\
\text { lower limb amputations } \\
\text { discharged from VAMCs } \\
\text { between } 1 \text { October } 2002 \text { and } \\
30 \text { September } 2003 \text { ( } 629 \text { of } \\
\text { whom received a prosthetic } \\
\text { prescription) }\end{array}$ & $\begin{array}{l}98.9 \% \text { male } \\
1.1 \% \text { female } \\
\text { (overall } \\
\text { sample) }\end{array}$ & $\begin{array}{l}80 \% \mathrm{BK} \\
19.9 \% \text { AK } \\
0.2 \% \text { hip } \\
\text { disarticulation } \\
\text { (participants } \\
\text { prescribed } \\
\text { prosthesis only) }\end{array}$ & Not reported & Not reported & $\begin{array}{l}90.4 \text { days from } \\
\text { surgery to } \\
\text { prosthetic } \\
\text { ordering date } \\
\text { (participants } \\
\text { prescribed } \\
\text { prosthesis only) }\end{array}$ & $2+$ \\
\hline $\begin{array}{l}\text { Larner et al. } \\
\text { (2003) }\end{array}$ & UK & $\begin{array}{l}\text { Cross- } \\
\text { sectional } \\
\text { (analytic) }\end{array}$ & $\begin{array}{l}\text { Inpatient } \\
\text { rehabilitation unit } \\
\text { offering prosthetic } \\
\text { provision }\end{array}$ & $\begin{array}{l}43 \text { persons with lower limb } \\
\text { amputations suffering from } \\
\text { peripheral vascular disease } \\
\text { with or without diabetes } \\
\text { admitted to a } \\
\text { multidisciplinary } \\
\text { rehabilitation ward }\end{array}$ & $\begin{array}{l}77 \% \text { male } \\
23 \% \text { female }\end{array}$ & $\begin{array}{l}49 \% \mathrm{BK} \\
51 \% \mathrm{AK}\end{array}$ & $100 \%$ PVD & 66.35 years & $\begin{array}{l}19 \text { days between } \\
\text { surgery and } \\
\text { admission to } \\
\text { facility }\end{array}$ & $2+$ \\
\hline
\end{tabular}

URL: http:/mc.manuscriptcentral.com/dandr Email: davemuller@suffolk.ac.uk 


\begin{tabular}{|c|c|c|c|c|c|c|c|c|c|c|}
\hline $\begin{array}{l}\text { O'Neill \& } \\
\text { Evans (2009) }\end{array}$ & UK & $\begin{array}{l}\begin{array}{l}\text { Prospective } \\
\text { cohort }\end{array} \\
\text { T1 = first } \\
\text { prosthetic } \\
\text { clinic } \\
\text { attendance } \\
\text { T2 = 6 months } \\
\text { later }\end{array}$ & $\begin{array}{l}\text { Regional limb- } \\
\text { fitting centre }\end{array}$ & $\begin{array}{l}34 \text { persons with lower limb } \\
\text { amputations referred to a } \\
\text { regional limb fitting centre } \\
\text { and deemed suitable for limb } \\
\text { fitting }\end{array}$ & $\begin{array}{l}82.4 \% \text { male } \\
17.6 \% \\
\text { female }\end{array}$ & $\begin{array}{l}55.9 \% \mathrm{BK} \\
44.1 \% \mathrm{AK}\end{array}$ & $\begin{array}{l}52.9 \% \text { PAD } \\
26.5 \% \text { PAD and } \\
\text { comorbid diabetes } \\
\text { mellitus } \\
5.9 \% \text { trauma } \\
5.9 \% \text { cancer } \\
5.9 \% \text { intravenous } \\
\text { drug use } \\
2.9 \% \text { acute } \\
\text { ischaemic episode }\end{array}$ & 60.7 years & Not reported & $2++$ \\
\hline $\begin{array}{l}\text { O'Neill et al. } \\
\text { (2010) }\end{array}$ & UK & $\begin{array}{l}\text { Randomised } \\
\text { crossover trial }\end{array}$ & $\begin{array}{l}\text { Regional limb- } \\
\text { fitting centre }\end{array}$ & $\begin{array}{l}8 \text { persons with lower limb } \\
\text { amputations who had } \\
\text { problems learning the correct } \\
\text { behavioural sequence in } \\
\text { putting on their prosthetic } \\
\text { limbs during rehabilitation }\end{array}$ & Not reported & $100 \% \mathrm{BK}$ & $\begin{array}{l}75 \% \text { PVD } \\
25 \% \text { diabetes } \\
\text { mellitus }\end{array}$ & 64 years & 147 days & $1+$ \\
\hline $\begin{array}{l}\text { Pauley et al. } \\
(2006)\end{array}$ & Canada & $\begin{array}{l}\text { Retrospective } \\
\text { cohort }\end{array}$ & $\begin{array}{l}\text { Inpatient } \\
\text { rehabilitation unit } \\
\text { (chart review) }\end{array}$ & $\begin{array}{l}1,267 \text { persons with major } \\
\text { lower limb amputations who } \\
\text { received inpatient } \\
\text { rehabilitation between April } \\
1998 \text { and September } 2003\end{array}$ & $\begin{array}{l}67 \% \text { male } \\
33 \% \text { female }\end{array}$ & $\begin{array}{l}56 \% \mathrm{BK} \\
27.5 \% \mathrm{AK} \\
16.5 \% \text { bilateral }\end{array}$ & $\begin{array}{l}84.4 \% \\
\mathrm{PVD} / \text { diabetes } \\
2.9 \% \text { trauma } \\
2 \% \text { tumour } \\
10.7 \% \text { other }\end{array}$ & 66.7 years & Not reported & $2+$ \\
\hline $\begin{array}{l}\text { Phillips et al. } \\
\text { (1993) }\end{array}$ & Canada & Case-control & $\begin{array}{l}\text { Tertiary care centre } \\
\text { for physical } \\
\text { rehabilitation, } \\
\text { community (social } \\
\text { clubs, senior } \\
\text { exercise classes) }\end{array}$ & $\begin{array}{l}14 \text { persons with lower limb } \\
\text { amputations secondary to } \\
\text { peripheral vascular disease } \\
\text { attending a tertiary care } \\
\text { centre for physical } \\
\text { rehabilitation and } 14 \\
\text { community-dwelling healthy } \\
\text { controls matched for age and } \\
\text { education }\end{array}$ & $\begin{array}{l}71 \% \text { male } \\
29 \% \text { female } \\
\text { (amputation } \\
\text { group only) }\end{array}$ & $\begin{array}{l}50 \% \mathrm{BK} \\
36 \% \text { AK } \\
14 \% \text { bilateral }\end{array}$ & $100 \%$ PVD & $\begin{array}{l}67.4 \text { years } \\
\text { (amputation } \\
\text { group only) }\end{array}$ & Not reported & $2+$ \\
\hline $\begin{array}{l}\text { Pinzur et al. } \\
\text { (1988) }\end{array}$ & USA & $\begin{array}{l}\text { Cross- } \\
\text { sectional (non- } \\
\text { analytic) }\end{array}$ & $\begin{array}{l}\text { Inpatient } \\
\text { rehabilitation unit }\end{array}$ & $\begin{array}{l}60 \text { persons with major lower } \\
\text { limb amputations considered } \\
\text { to be candidates for } \\
\text { prosthetic limb fitting and } \\
\text { rehabilitation by a } \\
\text { multidisciplinary team }\end{array}$ & $100 \%$ male & $\begin{array}{l}45 \% \text { BK } \\
8 \% \text { through-knee } \\
22 \% \text { AK } \\
25 \% \text { bilateral }\end{array}$ & $\begin{array}{l}90 \% \text { peripheral } \\
\text { vascular } \\
\text { insufficiency } \\
7 \% \text { trauma } \\
3 \% \text { frostbite }\end{array}$ & 60.3 years & Not reported & 3 \\
\hline $\begin{array}{l}\text { Remes et al. } \\
\text { (2008) }\end{array}$ & Finland & $\begin{array}{l}\text { Retrospective } \\
\text { cohort }\end{array}$ & $\begin{array}{l}2 \text { hospitals in Turku, } \\
\text { Finland (chart } \\
\text { review) }\end{array}$ & $\begin{array}{l}210 \text { persons who underwent } \\
\text { primary major lower limb } \\
\text { amputation due to peripheral } \\
\text { vascular disease between } \\
1998 \text { and } 2002 \text { in Turku, } \\
\text { Finland }\end{array}$ & $\begin{array}{l}45.2 \% \text { male } \\
54.8 \% \\
\text { female }\end{array}$ & $\begin{array}{l}25 \% \mathrm{BK} \\
75 \% \mathrm{AK}\end{array}$ & $\begin{array}{l}100 \% \text { peripheral } \\
\text { arterial disease }\end{array}$ & 76.6 years & Not reported & $2+$ \\
\hline $\begin{array}{l}\text { Remes et al. } \\
(2009)\end{array}$ & Finland & $\begin{array}{l}\text { Retrospective } \\
\text { cohort }\end{array}$ & $\begin{array}{l}2 \text { hospitals in Turku, } \\
\text { Finland }\end{array}$ & $\begin{array}{l}119 \text { peripheral vascular } \\
\text { disease patients admitted }\end{array}$ & $\begin{array}{l}48 \% \text { male } \\
52 \% \text { female }\end{array}$ & $\begin{array}{l}31 \% \mathrm{BK} \\
62 \% \mathrm{AK} \\
\end{array}$ & $100 \%$ PVD & 73.6 years & Not reported & $2+$ \\
\hline
\end{tabular}

URL: http:/mc.manuscriptcentral.com/dandr Email: davemuller@suffolk.ac.uk 


\begin{tabular}{|c|c|c|c|c|c|c|c|c|c|c|}
\hline & & & & $\begin{array}{l}\text { from home who underwent } \\
\text { primary major lower limb } \\
\text { amputation between } 1998 \\
\text { and } 2002 \text { and survived at } \\
\text { least one month after the } \\
\text { operation }\end{array}$ & & $7 \%$ bilateral & & & & \\
\hline $\begin{array}{l}\text { Schoppen et } \\
\text { al. (2003) }\end{array}$ & $\begin{array}{l}\text { The } \\
\text { Netherlands }\end{array}$ & $\begin{array}{l}\begin{array}{l}\text { Prospective } \\
\text { cohort }\end{array} \\
\text { T1 }=2 \text { weeks } \\
\text { post- } \\
\text { amputation } \\
\text { T2 = } 6 \text { weeks } \\
\text { post- } \\
\text { amputation } \\
\text { T3 = 6 months } \\
\text { post- } \\
\text { amputation } \\
\text { T4 } 1 \text { year } \\
\text { post- } \\
\text { amputation) }\end{array}$ & $\begin{array}{l}\text { Main hospitals, } \\
\text { rehabilitation } \\
\text { centres, nursing } \\
\text { homes, patients' } \\
\text { own residence } \\
\text { settings in } 1 \text { of the } 3 \\
\text { northern provinces } \\
\text { of the Netherlands }\end{array}$ & $\begin{array}{l}46 \text { persons aged over } 60 \\
\text { years with unilateral major } \\
\text { lower limb amputations due } \\
\text { to peripheral vascular disease } \\
\text { with or without diabetes and } \\
\text { living in one of the } 3 \\
\text { northern provinces in the } \\
\text { Netherlands }\end{array}$ & $\begin{array}{l}70 \% \text { male } \\
30 \% \text { female }\end{array}$ & $\begin{array}{l}72 \% \text { BK } \\
17 \% \text { through- } \\
\text { knee } \\
11 \% \text { AK }\end{array}$ & $100 \%$ PVD & 73.9 years & Not reported & $2++$ \\
\hline $\begin{array}{l}\text { Taylor et al. } \\
(2005)\end{array}$ & USA & $\begin{array}{l}\text { Retrospective } \\
\text { cohort }\end{array}$ & $\begin{array}{l}\text { Non-university } \\
\text { teaching centre } \\
\text { hospital (chart } \\
\text { review) }\end{array}$ & $\begin{array}{l}553 \text { persons who underwent } \\
627 \text { major lower limb } \\
\text { amputations between January } \\
1998 \text { and December } 2003 \text { at } \\
\text { a single non-university } \\
\text { teaching centre }\end{array}$ & $\begin{array}{l}55 \% \text { male } \\
45 \% \text { female }\end{array}$ & $\begin{array}{l}37.6 \% \text { BK } \\
4.3 \% \text { through- } \\
\text { knee } \\
34.5 \% \text { AK } \\
23.6 \% \text { bilateral }\end{array}$ & Not reported & 63.7 years & $\begin{array}{l}525 \text { days from } \\
\text { surgery to } \\
\text { follow-up }\end{array}$ & $2+$ \\
\hline $\begin{array}{l}\text { Taylor et al. } \\
(2007)\end{array}$ & USA & $\begin{array}{l}\text { Retrospective } \\
\text { cohort }\end{array}$ & $\begin{array}{l}\text { University medical } \\
\text { centre (chart review) }\end{array}$ & $\begin{array}{l}314 \text { persons identified from a } \\
\text { prospective vascular registry } \\
\text { as physiologically impaired } \\
\text { or unsuitable for open } \\
\text { surgery ( } 183 \text { persons } \\
\text { underwent major lower limb } \\
\text { amputation and } 131 \text { persons } \\
\text { underwent percutaneous } \\
\text { transluminal angioplasty) }\end{array}$ & $\begin{array}{l}54.1 \% \text { male } \\
45.9 \% \\
\text { female } \\
\text { (amputation } \\
\text { group only) }\end{array}$ & $\begin{array}{l}49 \% \text { AK } \\
3 \% \text { through-knee } \\
35 \% \text { BK } \\
13 \% \text { bilateral }\end{array}$ & $\begin{array}{l}100 \% \text { critical limb } \\
\text { ischaemia }\end{array}$ & Not reported & $\begin{array}{l}459 \text { days from } \\
\text { surgery to } \\
\text { follow-up } \\
\text { (amputation } \\
\text { group only) }\end{array}$ & $2+$ \\
\hline $\begin{array}{l}\text { Wang et al. } \\
(1975)\end{array}$ & USA & Case-control & $\begin{array}{l}\text { Rehabilitation } \\
\text { hospital }\end{array}$ & $\begin{array}{l}90 \text { persons admitted to a } \\
\text { rehabilitation hospital during } \\
\text { the year } 1973 \text { ( } 60 \text { hemiplegic } \\
\text { patients and } 30 \text { amputee } \\
\text { control patients) }\end{array}$ & $\begin{array}{l}47 \% \text { male } \\
53 \% \text { female } \\
\text { (amputation } \\
\text { group only) }\end{array}$ & Not reported & $\begin{array}{l}100 \% \text { poor } \\
\text { circulation } \\
\text { secondary to } \\
\text { diabetes mellitus }\end{array}$ & 59.7 years & Not reported & $2+$ \\
\hline
\end{tabular}

URL: http:/mc.manuscriptcentral.com/dandr Email: davemuller@suffolk.ac.uk 


\begin{tabular}{|c|c|c|c|c|c|c|c|c|c|c|}
\hline $\begin{array}{l}\text { Weiss et al. } \\
\text { (1990) }\end{array}$ & USA & $\begin{array}{l}\text { Cross- } \\
\text { sectional } \\
\text { (analytic) }\end{array}$ & Veterans hospital & $\begin{array}{l}97 \text { veteran amputees who } \\
\text { underwent } 155 \text { lower } \\
\text { extremity procedures during } \\
1984\end{array}$ & $\begin{array}{l}99 \% \text { male } \\
1 \% \text { female }\end{array}$ & $\begin{array}{l}25 \% \text { toe, foot or } \\
\text { ankle } \\
28 \% \text { BK } \\
29 \% \text { AK } \\
3 \% \text { hip } \\
\text { disarticulation } \\
15 \% \\
\text { debridement or } \\
\text { secondary } \\
\text { disclosure } \\
\end{array}$ & $\begin{array}{l}\text { Not reported (75\% } \\
\text { had PVD) }\end{array}$ & $\begin{array}{l}64 \text { years } \\
\text { (median age) }\end{array}$ & $\begin{array}{l}15 \text { months } \\
\text { between surgery } \\
\text { and follow-up }\end{array}$ & $2-$ \\
\hline $\begin{array}{l}\text { Willrich et al. } \\
\text { (2005) }\end{array}$ & USA & Case-control & Not reported & $\begin{array}{l}60 \text { persons with diabetes }(20 \\
\text { persons with lower limb } \\
\text { amputations, } 20 \text { persons with } \\
\text { diabetic foot ulcers or active } \\
\text { Charcot foot arthropathy, } 20 \\
\text { persons without foot-related } \\
\text { morbidity but with evidence } \\
\text { of peripheral neuropathy) }\end{array}$ & $\begin{array}{l}5 \% \text { male } \\
55 \% \text { female } \\
\text { (amputation } \\
\text { group only) }\end{array}$ & Not reported & Not reported & Not reported & Not reported & $2-$ \\
\hline $\begin{array}{l}\text { Yu et al. } \\
\text { (2010) }\end{array}$ & Canada & $\begin{array}{l}\text { Retrospective } \\
\text { cohort }\end{array}$ & $\begin{array}{l}\text { tertiary acute care } \\
\text { hospitals in Calgary, } \\
\text { Alberta, Canada } \\
\text { (chart review) }\end{array}$ & $\begin{array}{l}370 \text { persons undergoing } \\
\text { unilateral major lower limb } \\
\text { amputations in one of } 3 \\
\text { tertiary acute care hospitals }\end{array}$ & $\begin{array}{l}\text { Reported in } \\
\text { bar chart } \\
\text { form only }\end{array}$ & $\begin{array}{l}\text { Reported in bar } \\
\text { chart form only }\end{array}$ & $\begin{array}{l}\text { Reported in bar } \\
\text { chart form only }\end{array}$ & $64 . .6$ years & Not reported & $2+$ \\
\hline
\end{tabular}

Abbreviations used: RCT = randomised controlled trial; $\mathrm{PVD}=$ peripheral vascular disease; $\mathrm{BK}=$ below-knee; $\mathrm{AK}=$ above-knee; SIGN = Scottish Intercollegiate Guidelines Network

SIGN evidence level ranks: $1++=$ high quality RCTs with a very low risk of bias; $1+=$ well-conducted RCTs with a low risk of bias; $1-=$ RCTs with a high risk of bias; $2++=$ high quality case-control or cohort studies with a very low risk of confounding, bias, or chance and a high probability that the relationship is causal; $2+=$ well-conducted case-control or cohort studies with a low risk of confounding, bias, or chance and a moderate probability that the relationship is causal; $2-=$ case-control or cohort studies with a high risk of confounding, bias, or chance and a significant risk that the relationship is not causal; $3=$ non-analytic studies e.g. case reports, case series; $4=$ expert opinion 
Table 2. Summary of findings from included studies relating to cognitive functioning in persons with lower limb amputations.

\begin{tabular}{|c|c|c|c|}
\hline Study & Means of cognitive assessment & $\begin{array}{l}\text { Outcome measures associated with cognitive } \\
\text { functioning }\end{array}$ & Findings \\
\hline $\begin{array}{l}\text { Aftabuddin et al. } \\
\text { (1997) }\end{array}$ & Presence of dementia (from medical charts) & Rehabilitative failure & $\begin{array}{l}\text { Presence of dementia was the reason cited for rehabilitative failure in } 9 \% \text { of the } \\
265 \text { patients who received a prosthesis. }\end{array}$ \\
\hline Bates et al. (2009) & FIM cognitive score & Admission to specialised rehabilitation unit & $\begin{array}{l}\text { Patients admitted to a specialised rehabilitation unit (SRU) had better cognition } \\
\text { than those who were not admitted. After removing the effects of diagnoses, patients } \\
\text { with the lowest and highest cognitive scores were less often selected for SRU } \\
\text { admission. }\end{array}$ \\
\hline $\begin{array}{l}\text { Bilodeau et al. } \\
\text { (2000) }\end{array}$ & Short Portable Mental Status Questionnaire & Prosthesis use & $\begin{array}{l}\text { Prosthesis use was significantly related to better cognition. Cognition was an } \\
\text { independent predictor of prosthesis use, explaining a unique } 5 \% \text { of the variance. } \\
\text { Patient satisfaction, not possessing a wheelchair, and cognition together explained } \\
46 \% \text { of the variance in prosthesis use. }\end{array}$ \\
\hline $\begin{array}{l}\text { Campbell et al. } \\
\text { (2001) }\end{array}$ & Presence of dementia (from case notes) & Mortality & $\begin{array}{l}\text { Dementia was present in } 5 \% \text { of patients pre-operatively. } 44 \% \text { of patients with pre- } \\
\text { operative dementia died within } 30 \text { days of amputation surgery. Dementia was not } \\
\text { significantly associated with increased mortality. }\end{array}$ \\
\hline $\begin{array}{l}\text { Carmona et al. } \\
(2005)\end{array}$ & Presence of dementia (from medical charts) & Mortality & $\begin{array}{l}\text { The prevalence of dementia was } 15.8 \% \text { among patients. Dementia was } \\
\text { significantly associated with higher mortality after amputation. }\end{array}$ \\
\hline Chiu et al. (2000) & Physiatrist and psychologist assessment & Ambulation (community, indoors, or non-ambulation) & $\begin{array}{l}\text { Mental status was significantly related to ambulation outcome, and appeared to be } \\
\text { the most influential negative predictive factor of achieving community ambulation } \\
\text { in dual-disability patients. None of the five patients with impaired mental status } \\
\text { achieved community ambulation, and only one achieved indoor ambulation. }\end{array}$ \\
\hline Coetzee et al. (2008) & $\begin{array}{l}\text { Comprehensive Assessment of Prospective } \\
\text { Memory (CAPM) } \\
\text { Everyday Functioning Scale (EFQ) } \\
\text { Sheffield Screening Test for Acquired Language } \\
\text { Disorders (SST) } \\
\text { National Adult Reading Test-Revised (NART) } \\
\text { Rey Auditory-Verbal Learning Test (RAVLT) }\end{array}$ & Adherence to medical regimens & $\begin{array}{l}\text { Measures of language, prospective memory, planning and organisational abilities } \\
\text { were positively associated with adherence to medicine regimes among amputee } \\
\text { patients, as measured by self-reports and pill counts. Prospective memory and } \\
\text { emotional dysfunction together explained } 72.6 \% \text { of the variance in adherence to } \\
\text { medicines in this group. }\end{array}$ \\
\hline Couch et al. (1977) & Presence of dementia (from medical charts) & Rehabilitative failure & $\begin{array}{l}\text { Dementia was present in at least } 17 \% \text { of patients. Presence of dementia was the } \\
\text { reason cited for rehabilitative failure in } 16 \% \text { of patients. }\end{array}$ \\
\hline $\begin{array}{l}\text { Donaghey et al. } \\
\text { (2010) }\end{array}$ & $\begin{array}{l}\text { Addenbrookes Cognitive Examination-Revised } \\
\text { (ACE-R) }\end{array}$ & Not applicable & $\begin{array}{l}87 \% \text { of participants completed the ACE-R. The average score was } 83 \text {, with no } \\
\text { significant differences observed between experimental and control groups. Eleven } \\
\text { participants }(42 \%) \text { scored below the cut-off score for dementia }(=82) \text { on the ACE- }\end{array}$ \\
\hline
\end{tabular}

URL: http:/mc.manuscriptcentral.com/dandr Email: davemuller@suffolk.ac.uk 


\begin{tabular}{|c|c|c|c|}
\hline & & & $\begin{array}{l}\mathrm{R} \text {, five in the control group and } 6 \text { in the errorless learning group. Average scores on } \\
\text { the } A C E-R \text { subtests were as follows: attention and orientation }(M=16.2 / 20, S D= \\
2.2) \text {, memory }(M=19.5 / 26, S D=4.1) \text {, fluency }(M=9.5 / 14, S D=3.2) \text {, language } \\
(M=23.3 / 26, S D=2.2) \text {, and visuo-spatial ability }(M=14 / 16, S D=1.7) \text {. ACE-R } \\
\text { subtest scores did not differ significantly between groups. }\end{array}$ \\
\hline $\begin{array}{l}\text { Fletcher et al. } \\
\text { (2001) }\end{array}$ & Presence of dementia (from medical charts) & Prosthetic fitting & $\begin{array}{l}\text { Dementia was present in } 14 \% \text { of patients referred to a specialised amputee } \\
\text { rehabilitation clinic, compared with } 41 \% \text { of those not referred. Dementia was } \\
\text { significantly more prevalent in patients who were not referred to a specialized } \\
\text { amputee rehabilitation clinic than in those who were referred. Cognitive deficit was } \\
\text { the reason cited for unsuccessful prosthetic fit in } 21 \% \text { of cases }(n=26) \text {. Dementia } \\
\text { was a significant negative predictor of prosthetic fit, along with older age, presence } \\
\text { of cardiovascular disease, and having an above-knee amputation. }\end{array}$ \\
\hline $\begin{array}{l}\text { Gooday \& Hunter } \\
\text { (2004) }\end{array}$ & $\begin{array}{l}\text { Mini Mental State Examination } \\
\text { (MMSE)/intellectual functioning section of } \\
\text { Office of Population Censuses and Surveys } \\
\text { (OPCS)/record of 'confusion' or 'cognitive } \\
\text { impairment' in medical casenotes) }\end{array}$ & Experience of falls (single fall, multiple falls) & $\begin{array}{l}\text { Phase } 2: 33 \% \text { of all patients had cognitive impairment on admission. } 35 \%(\mathrm{n}=8) \\
\text { of patients who experienced a single fall were cognitively impaired. } 80 \%(\mathrm{n}=12) \\
\text { of patients who had multiple falls were cognitively impaired. Accidents appeared } \\
\text { to be more likely in cognitively impaired patients in the over } 70 \text { age group, but this } \\
\text { was not statistically significant. } \\
\text { Phase 3: } 29 \% \text { of all patients had cognitive impairment on admission. }\end{array}$ \\
\hline $\begin{array}{l}\text { Hanspal \& Fisher } \\
\text { (1991) }\end{array}$ & $\begin{array}{l}\text { Clifton Assessment Procedures for the Elderly } \\
\text { (CAPE) }\end{array}$ & Harold Wood/Stanmore mobility grade & $\begin{array}{l}\text { Orientation and mental ability were both positively associated with mobility grade. } \\
\text { Greater time taken and a higher number of errors on the psychomotor task were } \\
\text { associated with poorer mobility, as was a lower composite psychomotor scale } \\
\text { score. There was a significant positive correlation between total cognition scores } \\
\text { and the mobility of elderly patients. A total score of at least } 30 \text { was associated with } \\
\text { the ability to walk indoors and outdoors in patients without medical factors limiting } \\
\text { mobility. Of those who achieved a score of } 30 \text { or more, only } 4 \% \text { were unable to } \\
\text { walk outdoors. Only } 2 \% \text { of those who scored less than } 30 \text { could walk outdoors. }\end{array}$ \\
\hline $\begin{array}{l}\text { Hanspal \& Fisher } \\
\text { (1997) }\end{array}$ & CAPE & Harold Wood/Stanmore mobility grade & $\begin{array}{l}\text { There was a strong positive correlation between cognition at } 2-4 \text { weeks and at } 8-14 \\
\text { months post-amputation. The correlation between mobility and cognition was } \\
\text { significantly positive, with cognitive status accounting for approximately } 20 \% \text { of } \\
\text { the variance in mobility for the sample as a whole }(n=32) \text {. In patients who had no } \\
\text { medical complications }(n=12) \text {, the correlation between intellectual status and } \\
\text { mobility was } 0.92 \text {, with intellectual status accounting for } 85 \% \text { of the variance in } \\
\text { mobility. }\end{array}$ \\
\hline $\begin{array}{l}\text { Heinemann et al. } \\
\text { (1994) }\end{array}$ & FIM cognitive score & $\begin{array}{l}\text { Discharge FIM motor score } \\
\text { Discharge FIM cognitive score } \\
\text { Length of stay at rehabilitation facility }\end{array}$ & $\begin{array}{l}\text { In the amputation group, cognitive function on admission was a significant } \\
\text { predictor of discharge motor function. } 78 \% \text { of the variance in discharge cognitive } \\
\text { functioning was accounted for, with cognitive functioning on admission being the } \\
\text { only significant predictor. Admission cognitive function was not significantly } \\
\text { associated with length of stay. }\end{array}$ \\
\hline
\end{tabular}

URL: http:/mc.manuscriptcentral.com/dandr Email: davemuller@suffolk.ac.uk 


\begin{tabular}{|c|c|c|c|}
\hline Kurichi et al. (2007) & FIM cognitive score & Prosthetic prescription & $\begin{array}{l}\text { Patients in the highest functioning cognitive category (score of 29-35) were } 1.67 \\
\text { times as likely to receive a prosthetic prescription as patients in the lowest category } \\
\text { (score of 5-13). }\end{array}$ \\
\hline Larner et al. (2003) & Kendrick Object Learning Test (KOLT) & Prosthetic prescription & $\begin{array}{l}\text { There was a significant difference in memory between patients who were fitted } \\
\text { with a prosthesis and those who were not. Logistic regression analyses showed that } \\
\text { memory was a significant predictor of prosthetic fit, along with level of } \\
\text { amputation. Using a cut-off of }>15 \text { on the KOLT, } 70 \% \text { of people were correctly } \\
\text { predicted as being either able or unable to use a prosthesis in a post hoc } \\
\text { classification of the data. In conjunction with level of amputation, this percentage } \\
\text { increased to } 81 \% \text {. Of those who learned to use a prosthesis, } 29 \text { out of } 31 \text { were } \\
\text { correctly identified. Of those who did not learn to use a prosthesis, } 6 \text { out of } 12 \text { were } \\
\text { correctly identified. }\end{array}$ \\
\hline $\begin{array}{l}\text { O'Neill \& Evans } \\
\text { (2009) }\end{array}$ & $\begin{array}{l}\text { Repeatable Battery for the Assessment of } \\
\text { Neuropsychological Status (RBANS) story } \\
\text { recall, figure recall, and figure copy subtests } \\
\text { Behavioural Assessment of the Dysexecutive } \\
\text { Syndrome (BADS) key search subtest } \\
\text { Addenbrooke Cognitive Assessment (ACE) } \\
\text { naming and comprehension subtests } \\
\text { Line bisection test } \\
\text { Test of verbal fluency } \\
\text { 9-hole peg test } \\
\text { Overall index of cognition }\end{array}$ & $\begin{array}{l}\text { Locomotor Capability Index (LCI) } \\
\text { Prosthesis use (number of hours worn per day) } \\
\text { Special Interest Group in Amputee Medicine (SIGAM) } \\
\text { mobility grade }\end{array}$ & $\begin{array}{l}\text { Patients with amputation secondary to peripheral arterial disease (PAD) and PAD } \\
\text { with diabetes had significantly lower scores on index of cognition than those with } \\
\text { other amputation etiologies (trauma, cancer and vascular disorder associated with } \\
\text { intravenous drug use). Visual memory was the only significant predictor of LCI } \\
\text { scores, accounting for } 24.8 \% \text { of the variance in this outcome. Verbal fluency, a } \\
\text { measure of executive function, was the only variable significantly correlated with } \\
\text { hours of prosthesis wearing, and accounted for } 17.1 \% \text { of the variance in this } \\
\text { outcome. Immediate memory was a significant predictor of SIGAM mobility } \\
\text { grade, accounting for } 58.2 \% \text { of the variance along with age, level of amputation, } \\
\text { and pain. }\end{array}$ \\
\hline O’Neill et al. (2010) & $\begin{array}{l}\text { RBANS } \\
\text { ACE-R } \\
\text { MMSE }\end{array}$ & Not applicable & $\begin{array}{l}\text { MMSE scores ranged from } 17 \text { to } 29 \text {, with a mean score of } 23 \text {. The mean RBANS } \\
\text { score was } 61.9 \text {, and the mean ACE-R score was } 72.9 \text {, placing the sample as a } \\
\text { whole in the impaired range of cognitive function on both measures. } 6 \text { out of } 8 \\
\text { participants were in the extremely low range on the RBANS, one was borderline, } \\
\text { and one was within the average range but with impaired index of executive } \\
\text { function. On the ACE-R, } 7 \text { of the } 8 \text { participants were below the cut-off for } \\
\text { significant cognitive impairment }(=88) \text { and one was above the cut-off. }\end{array}$ \\
\hline Pauley et al. (2006) & $\begin{array}{l}\text { Presence of cognitive impairment (from medical } \\
\text { charts) } \\
\text { FIM cognitive score }\end{array}$ & Experience of falls (single fall, multiple falls) & $\begin{array}{l}98 \text { of the } 1267 \text { patients included in the study }(8 \%) \text { had cognitive impairment. } \\
\text { Cognitive impairment was a significant predictor of both falling and experiencing } \\
\text { multiple falls. }\end{array}$ \\
\hline Phillips et al. (1993) & $\begin{array}{l}\text { Wechsler Adult Intelligence Scale-Revised } \\
\text { (WAIS-R) Wechsler Memory Scale-Revised } \\
\text { (WMS-R) } \\
\text { Rey-Osterreith Complex Figure Test } \\
\text { Recognition Tests for Faces and Words }\end{array}$ & Not applicable & $\begin{array}{l}\text { Individuals with amputations secondary to dysvascularity had significantly slower } \\
\text { psychomotor speed and poorer problem solving and abstract reasoning abilities } \\
\text { than those in the control group. There were also trends towards poorer performance } \\
\text { on measures of visuospatial skills, concentration, and oral fluency among those } \\
\text { with amputations. }\end{array}$ \\
\hline
\end{tabular}

URL: http:/mc.manuscriptcentral.com/dandr Email: davemuller@suffolk.ac.uk 


\begin{tabular}{|c|c|c|c|}
\hline & $\begin{array}{l}\text { Graded Naming Test } \\
\text { Controlled Oral Word Association Test } \\
\text { (COWAT) } \\
\text { Modified Card Sorting Test (MCST) }\end{array}$ & & \\
\hline Pinzur et al. (1988) & $\begin{array}{l}\text { Patients }<60 \text { years: } \\
\text { Test of Mental Functions of the Elderly } \\
\text { Auditory Verbal Learning Task } \\
\text { Rey's Complex Figure } \\
\text { Patients }>60 \text { years: } \\
\text { Doppelt version of WAIS } \\
\text { Russell version of WMS } \\
\text { Auditory Verbal Learning Task } \\
\text { Rey's Complex Figure }\end{array}$ & Prosthesis use (successful fit and training in its use) & $\begin{array}{l}\text { Of the } 60 \text { patients, } 15 \% \text { had deficits in cognitive ability considered severe enough } \\
\text { to limit their capacity to learn to use a prosthetic limb successfully. All of the } 43 \\
\text { patients considered good candidates for prosthetic rehabilitation based on } \\
\text { psychologic (cognitive and personality) testing were successfully fit with a } \\
\text { prosthesis and trained in its use. Of the } 9 \text { patients who had cognitive impairment, } \\
\text { only two were capable of even minimal use of their prosthesis, and none } \\
\text { approached their preamputation level of ambulation. }\end{array}$ \\
\hline Remes et al. (2008) & $\begin{array}{l}\text { ICD codes F00-F03, and G30/MMSE score of } \\
<18 \text { /notes of suspicion of memory impairment } \\
\text { in medical records }\end{array}$ & Mortality (survival at 31 days, one year, overall) & $\begin{array}{l}\text { Cognitive impairment was not a significant predictor of survival at } 31 \text { days, one } \\
\text { year, or overall. }\end{array}$ \\
\hline Remes et al. (2009) & $\begin{array}{l}\text { ICD codes F00-F03, and G30/MMSE score of } \\
<18 \text { /notes of suspicion of memory impairment } \\
\text { in medical records }\end{array}$ & Discharge to institutional care & $\begin{array}{l}\text { Cognitive impairment was not significantly associated with discharge into } \\
\text { institutional care. }\end{array}$ \\
\hline $\begin{array}{l}\text { Schoppen et al. } \\
\text { (2003) }\end{array}$ & $\begin{array}{l}\text { Cognitive Screening Test (CST) } \\
15 \text {-word test } \\
\text { Stroop Word-Colour Test (CWT) }\end{array}$ & $\begin{array}{l}\text { Sickness Impact Profile, 68-item version (SIP-68) } \\
\text { Groningen Activity Restriction Scale (GARS) } \\
\text { Timed-up-and-go (TUG) test } \\
\text { Prosthesis use }\end{array}$ & $\begin{array}{l}\text { Improvement was apparent on all cognitive measures from assessment at } 2 \text { weeks } \\
\text { postamputation to } 6 \text { weeks after amputation. On the CST, for example, at } 2 \text { weeks } \\
\text { after amputation } 22 \% \text { of the sample met the criteria for severe cognitive } \\
\text { impairment, but this dropped to } 9 \% \text { by } 6 \text { weeks post-amputation. Memory was a } \\
\text { significant predictor of perceived health status at one year postamputation, and } \\
\text { explained } 51 \% \text { of the variance along with } 1 \text {-leg balance and the presence of } \\
\text { comorbidities other than cardiopulmonary or diabetes. Memory was also a } \\
\text { significant predictor of activity restriction at one year postamputation, and } \\
\text { accounted for } 33 \% \text { of variance along with } 1-\text { leg balance. }\end{array}$ \\
\hline Taylor et al. (2005) & Presence of dementia (from medical charts) & $\begin{array}{l}\text { Prosthesis use } \\
\text { Mortality (survival at one year) } \\
\text { Maintenance of pre-operative independent status }\end{array}$ & $\begin{array}{l}\text { Presence of dementia preoperatively was an independent predictor of not wearing a } \\
\text { prosthesis, such that people with dementia were } 2.4 \text { times less likely to wear a } \\
\text { prosthesis after amputation. Failure to maintain independent living status was also } \\
\text { independently predicted by the presence of dementia, such that individuals with } \\
\text { dementia were } 1.6 \text { times less likely to maintain independent living status after } \\
\text { amputation. }\end{array}$ \\
\hline Taylor et al. (2007) & Presence of dementia (from medical charts) & $\begin{array}{l}\text { Mortality } \\
\text { Maintenance of pre-operative independent status }\end{array}$ & $\begin{array}{l}\text { 49.2\% of patients who underwent amputation had dementia, compared with } 29.8 \% \\
\text { of those who underwent pericutaneous transluminal angioplasty (PTA). Patients } \\
\text { with dementia had a significantly higher likelihood of undergoing amputation than }\end{array}$ \\
\hline
\end{tabular}

URL: http:/mc.manuscriptcentral.com/dandr Email: davemuller@suffolk.ac.uk 


\begin{tabular}{|c|c|c|c|}
\hline & & & $\begin{array}{l}\text { PTA. Patients with dementia who underwent amputation demonstrated a survival } \\
\text { advantage when compared with those who underwent PTA. Presence of dementia } \\
\text { preoperatively was a significant independent predictor of living status deterioration } \\
\text { from living independently to living non-independently. }\end{array}$ \\
\hline Wang et al. (1975) & WMS & Not applicable & $\begin{array}{l}\text { Individuals with amputations performed significantly better on the orientation to } \\
\text { self, temporal orientation, place orientation, mental control, digits backwards, and } \\
\text { digits total subtests of the WMS than left and right hemiplegics. They also obtained } \\
\text { a higher overall raw score and higher memory quotients than the other two groups. } \\
\text { The three experimental groups did not differ on the logical memory, associate } \\
\text { learning, or digits forward subtest. }\end{array}$ \\
\hline Weiss et al. (1990) & Confusion (method of assessment not reported) & Dependence in activities of daily living & $\begin{array}{l}\text { Confusion, along with high level of amputation, older age, confinement to an } \\
\text { institution, presence of stump pain, and poor self-rated health, were retained in the } \\
\text { regression model that best explained dependence. }\end{array}$ \\
\hline $\begin{array}{l}\text { Willrich et al. } \\
\text { (2005) }\end{array}$ & $\begin{array}{l}\text { MMSE } \\
\text { Clock drawing test }\end{array}$ & Not applicable & $\begin{array}{l}\text { Patients with amputations did not differ significantly from patients with diabetic } \\
\text { foot ulcers or Charcot arthropathy or controls on MMSE or clock drawing test } \\
\text { scores. }\end{array}$ \\
\hline Yu et al. (2010) & Cognitive deficits (from medical charts) & Experience of falls & $\begin{array}{l}16.5 \% \text { of the overall sample had cognitive impairment. A greater proportion of } \\
\text { falls was noted in persons with cognitive impairment, such that } 21.9 \% \text { of fallers } \\
\text { had cognitive impairment compared with } 12.6 \% \text { of those who did not experience a } \\
\text { fall. Cognitive impairment was not a significant risk factor for falling. }\end{array}$ \\
\hline
\end{tabular}


Implications for Rehabilitation

\section{$\underline{\text { Cognitive functioning in persons with lower limb amputations }}$}

- Cognitive impairment appears to be more prevalent among persons with lower limb amputations than in the general population.

- Cognitive impairment is negatively associated with mobility, prosthesis use, and maintenance of independence following amputation.

- Cognitive screening prior to rehabilitation could assist in determining patients' suitability for prosthetic or wheelchair use, ascertaining appropriate goals, and tailoring rehabilitation to patients' strengths so as to optimise their mobility and independence. 